\title{
Performance Analysis and Techno-Economic Optimization of Green Energy Systems for Remote Areas in the Maghreb
}

\author{
Hamza Siyoucef $^{1} \cdot$ Benameur Afif $^{1} \cdot$ Youcef Islam Djilani Kobibi $^{1} \cdot$ Samir Ghouali ${ }^{1,2}$ - Boualem Merabet ${ }^{1}$ (D) \\ Saad Motahhir ${ }^{3}$ (D)
}

Received: 3 April 2021 / Accepted: 2 August 2021 / Published online: 23 August 2021

(C) The Author(s), under exclusive licence to Springer Nature Singapore Pte Ltd. 2021

\begin{abstract}
All interventions that enhance livelihoods of poor rural families in remote areas of the Maghreb will positively impact standard living, involve technological solutions, and likely enhance agricultural production, which in turn can further contribute to poverty reduction. Hybrid green energy systems (HGESs) have been more exploited to supply a mobile base transceiver station (BTS) by clean electricity, or assess the energy availability in smart grids (SGs) of such areas. In this paper, a HGES has been modeled to produce energy from PV/Wind HGES in grid-connected BTS or SG sites, using MATLAB to solve a theoretical model, and simulated with a suitable configuration for performance analysis and optimal sizing. A techno-economic simulation, carried out using the HOMER package, has evaluated such HGES feeding BTS or SG in a remote area-prototype (RAP) of the Maghreb, and optimized the size and assess hybrid PV-Wind system based on weather conditions for RAP. The results may impact rural livelihood and improve standard living of people in such countries.
\end{abstract}

Keywords Sustainable energy $\cdot$ Hybrid energy System $\cdot$ Assessment $\cdot$ HOMER $\cdot$ Matlab $\cdot$ Maghreb

\section{Introduction}

Nowadays, energy is the crucial factor impacting countries' economic development, where energy demands have been growing sharply. [1] As a result of climate change, the world is facing to energy security, and dealing with social, economic, technological, environmental, risk management, and geopolitical problems that need to be solved [2]. Developing hybrid systems for renewable energy conversion has solved most of these problems in developed countries, provision of health services, distance education, staff development/support, using information technology to deliver/enhance services to rural/

Saad Motahhir

saad.motahhir@usmba.ac.ma

Hamza Siyoucef

https://www.editorialmanager.com/tesg/

1 Faculty of Sciences and Technology, University Mustapha Stambouli of Mascara, 29000 Mascara, Algeria

2 STIC Lab, Faculty of Sciences and Technology, University of Tlemcen, Tlemcen, Algeria

3 Ecole Nationale des Sciences Appliquées, Université Sidi Mohamed Ben Abdellah Fez, Fes, Morocco remote communities, in training and education, telemedicine, to improve life quality of disadvantaged persons. [3] This was achieved thanks to adequate telecom infrastructure powered by hybrid green energy systems (HGESs) with low energy consumption and power loss. [4]

In developing countries, however, financial losses due to unbalance cost result in power losses shortening equipment life for industrial customers. [5] Manufacturing productivity suffer mostly from electricity interruptions and power quality. [4] Nevertheless, telecom networks (TNs) are required in remote areas of such countries, after that network operators have established mobile services in the emerging markets [6]. Likely, smart grids (SGs) in these areas are notably important, in face of increasing energy supply-demand stress with rapid urbanization and increase in life quality [7, 8].

In remote areas, high-voltage power grids (HVPGs) feeding costly microwave and base transceiver station (BTS) equipments [9-11], or SGs monitoring energy consumption and efficiency of HVPGs using TNs, are needed [12-16]. However, TNs mainly expanded to highest remote forests in these areas, are confronted to their non-existence and the instability or even inadequacy of HVPGs [17], that need huge budgets to be upgraded/reformed [18]. Luckily, these eloigned regions own abundant solar and wind, so as HGESs remain an 
ideal choice to power supply BTS equipments fed by HVPGs, or feed SGs controlling HVPGs consumption, hence save such costly equipments [19]. Besides major consumption issues TNs suffer from being long depended on diesel generators (DGs), that operate expensively, at low levels of efficiency, and produce high $\mathrm{CO}_{2}$ emissions [20]. Reversely, SGs involve load-, distributed- and energy storage-resources, and mainly include solar and wind HGES generation, and manageable distributed resources generation [21], so as to lower operating cost and reduce greenhouse gas and pollutant emissions [22]. Hence, it is necessary to prevent such situation harmful for both TNs and SGs. For instance, mobile operators need unremitting electrical power supply to keep TNs continuously functional, ovoid their failure by interrupting supply electricity during load-shedding periods, thus deploy DGs in BTS sites as backup power supply [23]. Africa to which the Maghreb belongs, has intently suffered from a lower urbanization rate and break power supply systems, continuing to roll out $4 \mathrm{G}$ networks, while the globe communication industry attests today a stiff competition and stagnating revenue growth, to define $5 \mathrm{G}$ network requirements. Motivated by relevant works [24-30], in the context of lowering the energy cost and enhancing the network operation, we have chosen three (3) remote areas from the Maghreb: (Ras El Oued, Cherb Errih, and Ain Amara), owning closest location details and nearest average climate and daylight, situated at an altitude of $890 \mathrm{~m}$ (https://earth.google.com/) (https://www. ncdc.noaa.gov/ and https://weatherspark.com/), to be studied as a unique case study within a remote area-prototype (RAP), as given in Fig. 1.

Strong efforts have to be made by our developing countries to reduce energy costs and improve the network operation in such remote areas, optimize energy cost, convert indoor BTS into outdoor one, eliminate using air conditioners, install energy efficient equipment, and exploit HGESs to feed TNs in the mentioned RAP [31-34].

\section{Hypothesis and Goals of the Study}

Besides having social costs, emigration of skilled people (mainly belonging to remote areas) from the Maghreb can prevent this region from investing in human capital. Improving rural livelihoods, beyond economic impacts, can boost agricultural industry, bring employment opportunities, hence limit emigration towards the developed world. On another hand, foreign tourists are usually getting lost in deserts and rural areas of the Maghreb. To help them safely enjoy their holydays and avoid probable critical situations, HGESs supplying BTS must be configured to localize them. This study has the following two main objectives:

It describes results of a photovoltaic (PV) cell model using Matlab-Simulink approach, and a techno-economic solution of employing hybrid HGESs to power a mobile telecom BTS in RAP, evaluated by HOMER software. Performance analysis and feasibility of a techno-economic solution is predicted, where an HGES alternative to DGs for BTS exhibit higher reliability and lower cost of energy production [35-39].

It aims also to answer a question: How best to harness TNs that reduce rural isolation, apply socio-technical approaches to strengthen SGs in remote areas of the Maghreb, and improve rural livelihoods? The novelty here is also that:

- Deep/high mountainous areas with insufficient rural electrification (like RAP here) may be probably targeted by tourists often lost (or attacked by malefactors), or scientists that gather information on roosting and foraging ecology of forest bats (threatening nearby agriculture) in such mountain environment.

- Conventional energy plants in the Maghreb are prone to external economic forces, which made this region depending on such energy sources to experience unpredictable variation in electricity supply to feed TNs whose performance is affected with such handicap, and TNs have to generate electricity for properly operating by using GRESs.

- Identifying techno economic criteria for the modeled GRES reveals wind turbines of weak contribution to supply TNs, compared to PV panels, and assessing the energy availability in SMGs of such areas are here of prime interest.

- Rare are researches optimizing configurations of HGES models to power supply TNs, or reversibly assess energy in SGs in the whole Maghreb. From literature and gaps noticed in works recognized above, here an in-between study is performed to analyze performance and technoeconomically optimize power HGESs costs for TNs in a RAP of such key-region, as gate between Europe and Africa.

- A PV-based HRES on the basis of two objectives Matlab/ Homer software is predicted to properly size and optimize performance that is estimated for optimal configurations with minimum net present cost (NPC) and levelized cost of energy (LCOE). This study reveals that such HRES has reasonable environmental benefits and is economically feasible.

- Basing on comparison annual wind speed price with LCOE and NPC, the sensitivity analysis carried out here favorite PV-based RESs as promising candidates for TNs in RAP.

\section{PV System Modeling and MPPT}

PV RERs, implemented with different topologies and control methodologies, are classified into two main categories: grid 


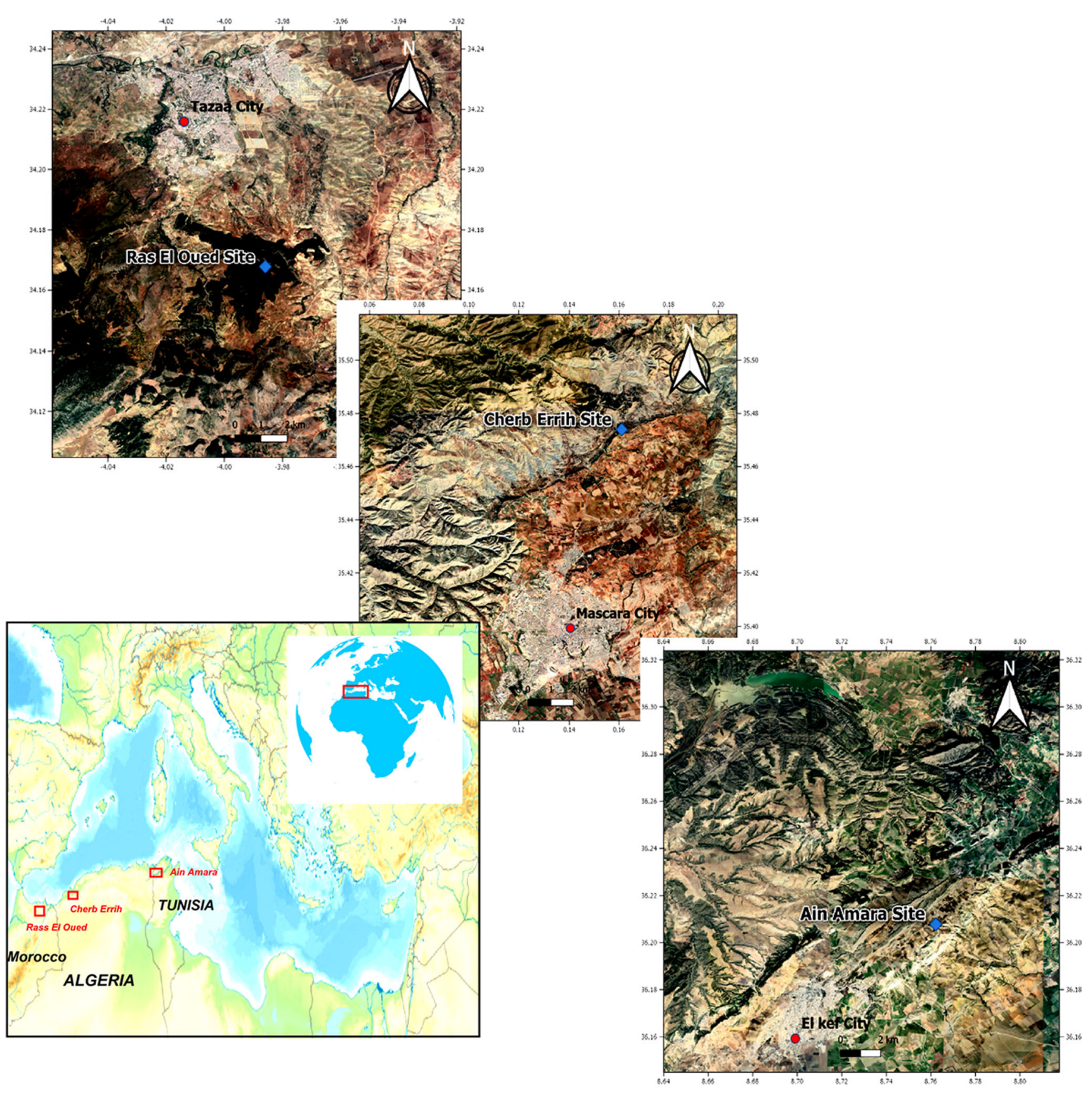

Fig. 1 Geographical locations and global climate of $a$ ) Ras El Oued (Taza) Morocco $\left(34^{\circ} 10^{\prime} 04^{\prime} \mathrm{N}, 3^{\circ} 59^{\prime} 09^{\prime} \mathrm{W}\right), b$ ) Cherb Errih, Mascara, Algeria $\left(35^{\circ} 28^{\prime} 26^{\prime \prime} \mathrm{N}, 0^{\circ} 09^{\prime} 40^{\prime \prime} \mathrm{E}\right)$, and $c$ ) Ain Amara, El-Kef, Tunisia $\left(36^{\circ} 12^{\prime} 28^{\prime \prime} \mathrm{N}, 8^{\circ} 45^{\prime} 44^{\prime \prime} \mathrm{E}\right)$. Average wind speed, respectively: $\left.a\right) 8.3$ to

and standalone connected applications [40], so as in the latter type a DC-DC converter is used between a DC load and PV sources for maximum power point tracking (MPPT) purposes [41]. In the standalone scheme, batteries as storage elements are necessary for the night hours, to solve the issue of installing a lot of panels to provide the energy that the load require [42], but these require frequent replacement [43], which increases the overall system cost [41]. Hence, a gridconnected topology is preferred, since it can be implemented
$7.3 \mathrm{mph}$; b) 8.4 to $9.5 \mathrm{mph}$; c) 9.6 to $8.3 \mathrm{mph}$, all windy in March and mi-Novomber to mi-December. Low-to-High ranges of temperature in July: $\left.\left.a)(20-35)^{\circ} \mathrm{C}, b\right)(19-36)^{\circ} \mathrm{C}, c\right)(16-34)^{\circ} \mathrm{C}$. (https://earth.google. com/) (https://www.ncdc.noaa.gov/ and https://weatherspark.com/)

by directly via coupling inverters to grids without including DC-DC converters [44]. Extensive computation requirements are disadvantaging the MPPT techniques that may be monitored by the MPPT system which choose the most appropriate one according to environmental conditions and application/load requirements. To simulate the model Voc, Isc, Vm, Im are needed, however, the PV system required accurate data to improve the performance of our HGES. 

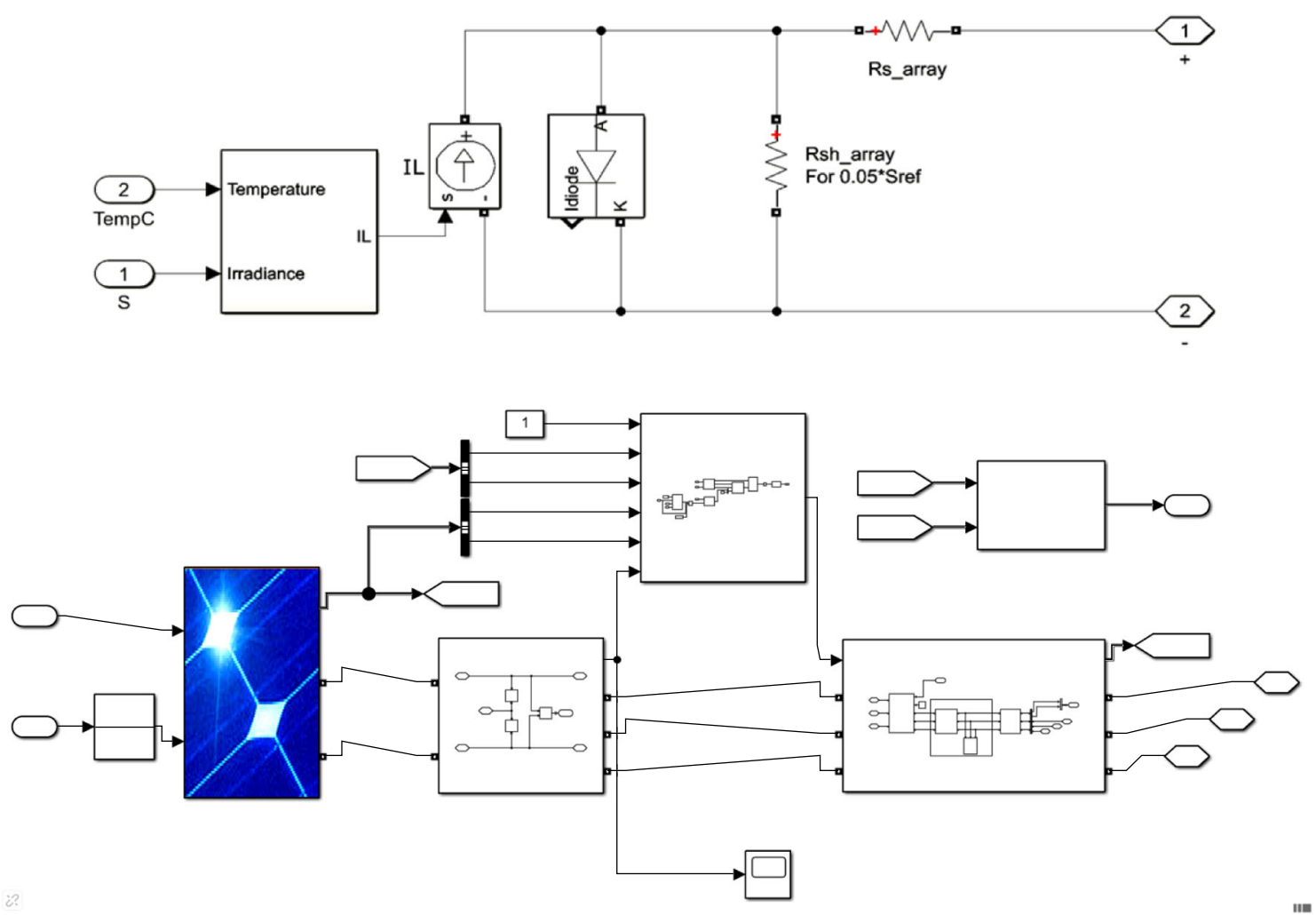

Fig. 2 PV cell one-diode equivalent circuit [47] (a) and schematic of the PV system (b) by Simulink

Here, PV cells offer lower output voltage, and the PV source is available in sixty (60) series cells panels and a single array to provide sufficient power to the BTS. Although parameters of PV cells can be estimated by using double and triple diode models [45] to describe the PV module behavior, the well known one-diode model (Fig. 2) is adopted here [46], so that:

$I_{\text {Out }}=I_{P V}-I_{S}\left[\exp \left(q\left(V_{\text {Out }}+I_{\text {Out }} R_{S}\right) / k T_{\text {Cell }} A-1\right]-\left(V_{\text {Out }}+I_{\text {Out }} R_{S}\right) / R_{S H}\right.$

Table 1 Characteristics of Solar World SW250 Mono module

\begin{tabular}{ll}
\hline Parameters & Specifications \\
\hline Maximum Power point $(\mathrm{MPP})\left(\mathrm{P}_{\max }\right)$ & $250.355 \mathrm{~W}$ \\
Voltage at peak power $\left(\mathrm{V}_{\max }\right)$ & $31.1 \mathrm{~V}$ \\
Current at peak power $\left(\mathrm{I}_{\max }\right)$ & $8.05 \mathrm{~A}$ \\
Open circuit voltage $\left(\mathrm{V}_{o c}\right)$ & $37.8 \mathrm{~V}$ \\
Short circuit current $\left(\mathrm{I}_{s c}\right)$ & $8.28 \mathrm{~A}$ \\
Temperature coefficient of Short circuit current $\left(\mathrm{K}_{I}\right)$ & $0.042 \% /{ }^{\circ} \mathrm{C}$ \\
Ideality Factor $(\mathrm{A})$ & 1.3 \\
Length $x$ Width $x$ Height $[\mathrm{mm}]$ & $1675 \times 1001 \times 34$ \\
Number of cells & 60 \\
Cell seize $[\mathrm{mm}]$ & $156 \times 156$ \\
Cellular Material & Si-mono \\
\hline
\end{tabular}

Where, $I_{\mathrm{PH}}, I_{\mathrm{S}}, q, k, T_{\mathrm{Cell}}, A, R_{\mathrm{SH}}$, and $\mathrm{R}_{\mathrm{S}}$ are respectively the photocurrent, dark saturation current of the cell, electron charge $\left(1.6 \times 10^{-19} \mathrm{C}\right)$, Boltzmann's constant $\left(1.38 \times 10^{-23} \mathrm{~J} /\right.$ $\mathrm{K})$, cell's working temperature, ideal factor, shunt resistance, series resistance. The photo generated current, mostly depending on solar radiation and working cell temperature, is: [47].

$I_{P V}=\left[I_{S C}\left(T_{r e f}\right)+K_{I}\left(T_{\text {cell }}-T_{r e f}\right)\right] \cdot G$

Where $I_{S C}\left(T_{r e f}\right), \mathrm{G}, \mathrm{K}_{\mathrm{I}}$ and $\mathrm{T}_{r e f}$ are respectively the shortcircuit current of the cell at reference temperature $\left(25^{\circ} \mathrm{C}\right)$ and standard radiation $\left(10^{3} \mathrm{~W} / \mathrm{m}^{2}\right)$, the temperature coefficient of cell's short circuit current, the reference temperature of the cell, and the solar insolation ( $\mathrm{G}$ in $\left.\mathrm{kW} / \mathrm{m}^{2}\right)$. Additionally, the diode reverse current as a function of the cell temperature is

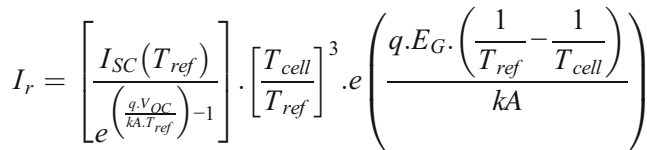

With a first term giving the reverse saturation current. The considered PV module has $n_{\mathrm{s}}$ in series and $n_{\mathrm{p}}$ cells, and in parallel configuration, respectively (here $n_{\mathrm{s}}$ and $n_{\mathrm{p}}$ are 60 and 1), as the equation below characterizing the I-V behavior for a simplest model describes [48], basing on Eqs. 2 and 3.

$I_{\text {Out }}=n_{p} I_{P V}-n_{p} I_{r} e^{\left[\left[\frac{q\left(n_{p} V_{\text {Out }}+n_{s} I_{\text {Out }} R_{s}\right)}{n_{p} n_{s} T_{\text {Tre }} A}\right]-1\right]}$ 
Fig. $3 \mathrm{P}-\mathrm{V}$ characteristics of $\mathrm{PV}$ modules under: $a$ ) different radiations and constant temperature $\left.\left(25^{\circ} \mathrm{C}\right), b\right)$ temperatures and constant radiation $\left(1000 \mathrm{~W} / \mathrm{m}^{2}\right)$

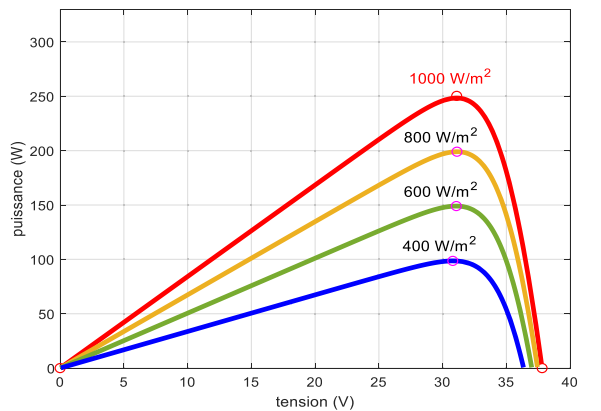

b)

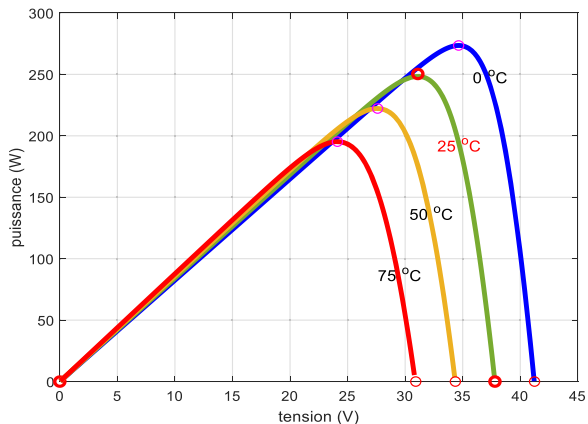

Where $I_{\text {Out }}$ and $V_{\text {Out }}$ are the output current and voltage. To observe effects of varying various parameters, a SW250 Mono module [49], with manufacturer specifications provided in Table 1, of $250 \mathrm{~W}$ is considered. From I-V and P-V characteristics, MPP picks are displayed regarding to power changes due to irradiation and temperature variations, and PV panel parameters at MPP are shown, such as the corresponding optimal voltage $\left(\mathrm{V}_{\mathrm{M}}\right)$ and current $\left(\mathrm{I}_{\mathrm{M}}\right)$, open circuit voltage $\left(\mathrm{V}_{\mathrm{OC}}\right)$, and short circuit current $\left(\mathrm{I}_{\mathrm{SC}}\right)$. At $\mathrm{SC}$ condition, $\mathrm{I}_{\mathrm{PV}}$ (Eq. 2) flows through $\mathrm{R}_{\mathrm{SH}}$ and $\mathrm{R}_{\mathrm{S}}$, since the diode does not conduct, essentially simplifying the circuit to a current divider. However, At OC condition, there is no voltage drop across the
$\mathrm{R}_{\mathrm{S}}$ and $\mathrm{I}_{\mathrm{PV}}$ mainly flows through the conducting diode. It is worth mentioning that neither $\mathrm{I}_{\mathrm{sc}}$ nor $\mathrm{V}_{\mathrm{oc}}$ are affected by the change of $R_{s}$, and the MPP moves to the right, so as the MPP power $\mathrm{P}_{\text {max }}$ should be in reverse proportion to $\mathrm{R}_{\mathrm{s}}$, which is in accordance with the fill factor $F F=P_{\max } /\left(V_{O C} . I_{S C}\right)$. Due to simplicity, Newton Raphson method [47] is used to calculate $\mathrm{I}_{\text {out }}$ current (Eq. 1). Figures 3, 4, 5 depict typical I-V and P-V characteristics of a single diode module model (Fig.2) under various irradiations and atmospheric conditions of temperature.

Figures $3(a)$ shows the presented model $I-V$ curves of the Solar World SW250 Mono at four different irradiations (400,
Fig. 4 I-V (upper panel) and P-V (lower panel) characteristics of the PV module under different radiations and constant temperature $\left(25^{\circ} \mathrm{C}\right)$
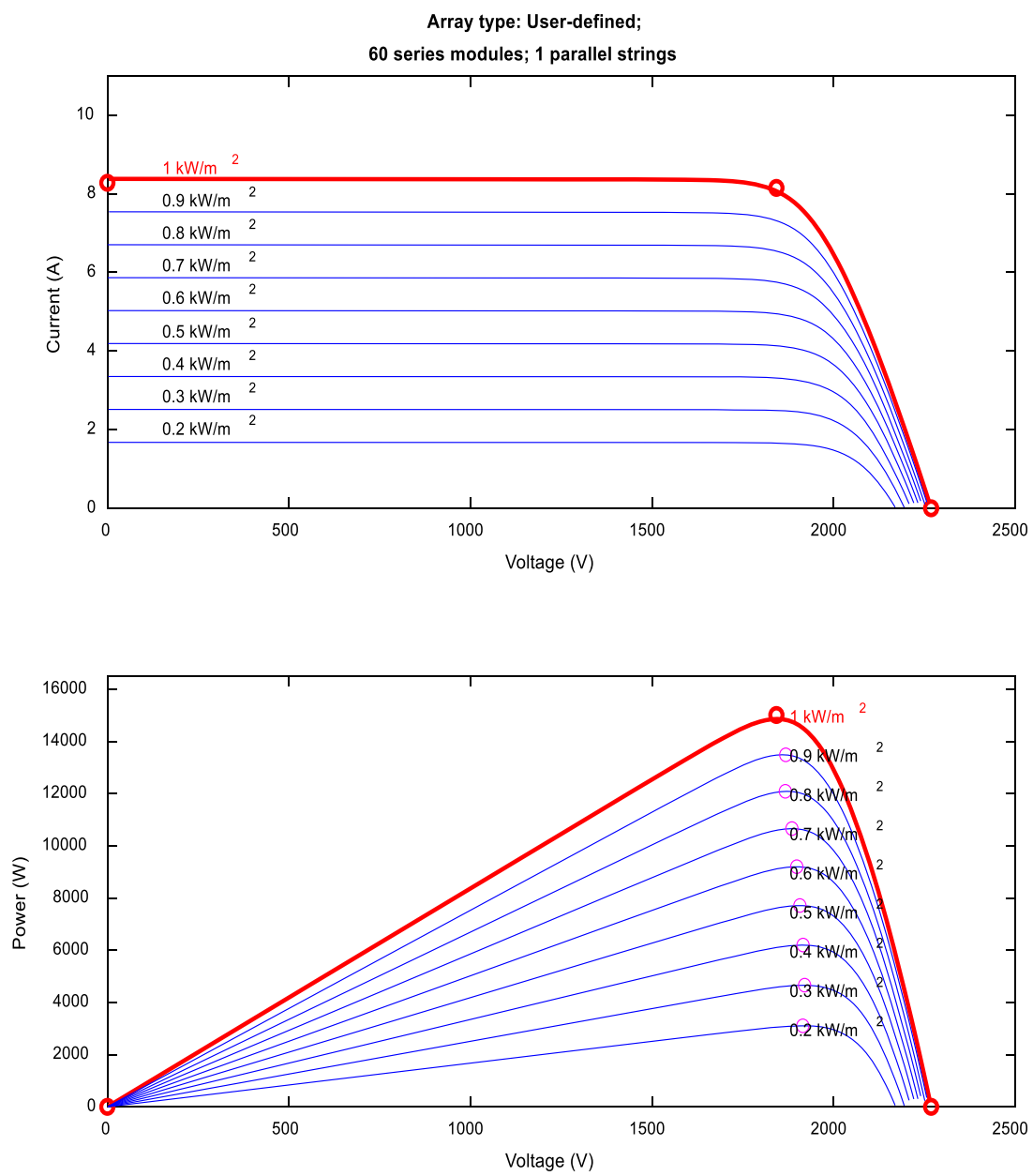

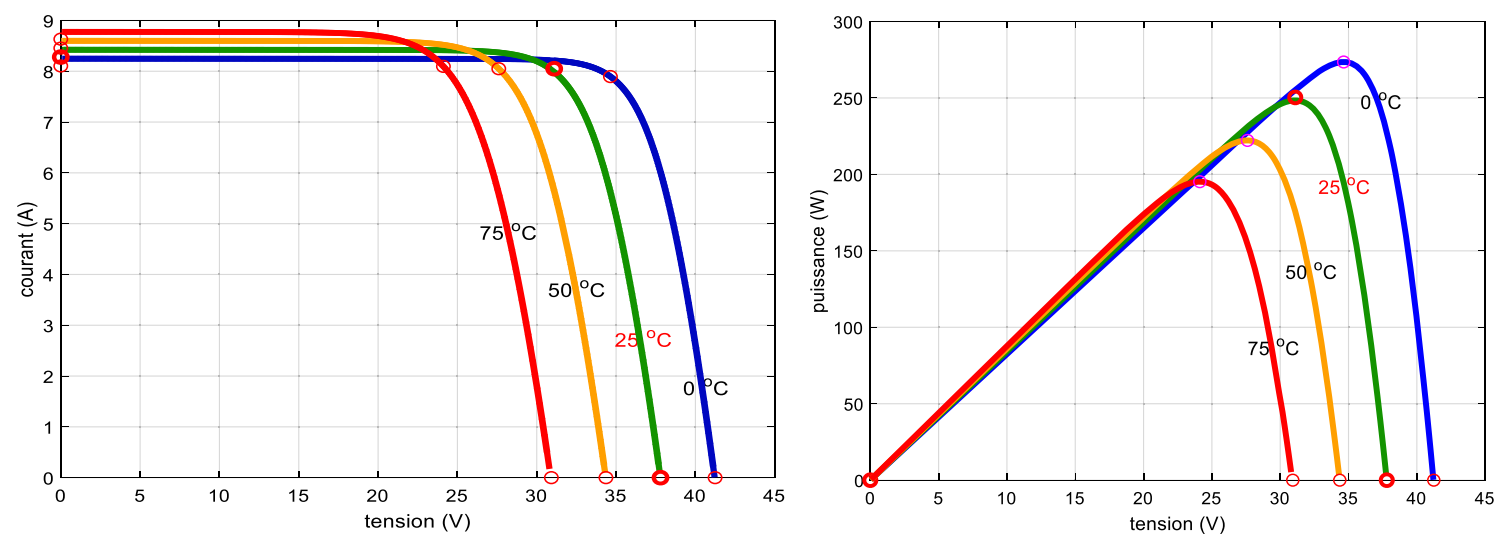

Fig. $5 \mathrm{I}-\mathrm{V}$ (left) and P-V (right) characteristics of the PV module under different temperature conditions and constant radiation $\left(\mathrm{G}=1000 \mathrm{~W} / \mathrm{m}^{2}\right)$

600,800 , and $\left.1000 \mathrm{~W} / \mathrm{m}^{2}\right)$ and constant temperature $\left(25^{\circ} \mathrm{C}\right)$, while Figs. 3 (b) illustrates model I-V curves at four (4) different temperatures conditions $\left(0,25,50\right.$, and $\left.75^{\circ} \mathrm{C}\right)$ and constant irradiation $\left(10^{3} \mathrm{~W} / \mathrm{m}^{2}\right)$, indicating three key operating points: $\mathrm{I}_{\mathrm{SC}}, \mathrm{V}_{\mathrm{OC}}$ and $\mathrm{P}_{\mathrm{MPP}}$. The results proved that simulated $\mathrm{I}-\mathrm{V}$ and $\mathrm{P}-\mathrm{V}$ characteristics accurately matches with those provided by fabricants, and acquiring I-V parameters from accurate discrete model with system functions is possible.

Matlab-Simulink calculates and analyze the output current and power of different PV module model using typical electrical parameters $\left(\mathrm{I}_{\mathrm{SC}}, \mathrm{V}_{\mathrm{OC}}, \mathrm{K}_{I}\right)$ of the chosen module. With an increases of radiation, module short circuit current increases proportionally while there is an insignificant increment in the open circuit voltage (Fig.5), which leads to an increase in $\mathrm{P}_{\text {max }}$, as shown in Fig.3. Contrary to an observed increase of the output voltage $\left(\mathrm{V}_{\text {OUT }}\right)$ when.

the irradiation increase with increasing of temperature, $\mathrm{V}_{\text {OUT }}$ decreases with the $\mathrm{p}-\mathrm{n}$ junction voltage temperature dependence. Hence, $\mathrm{V}_{\mathrm{OC}}$ owns a negative temperature coefficient (TC) of $-0.33 \% /{ }^{\circ} \mathrm{K}$, since higher temperature results in larger $\mathrm{I}_{\mathrm{PV}}$, the output current $\left(\mathrm{I}_{\mathrm{OUT}}\right)$ has a characteristic of positive TC, of $0.042 \% /{ }^{\circ} \mathrm{K}$ [50]. Since, $\mathrm{V}_{\text {OUT }}$ and $\mathrm{I}_{\text {OUT }}$ change with irradiance, effects of changing of temperature and irradiance should be considered in the PV module model [51]. It is worth noting that when one aims to achieve I-V and P-V
Fig. 6 Waveforms of PV Module voltage and current
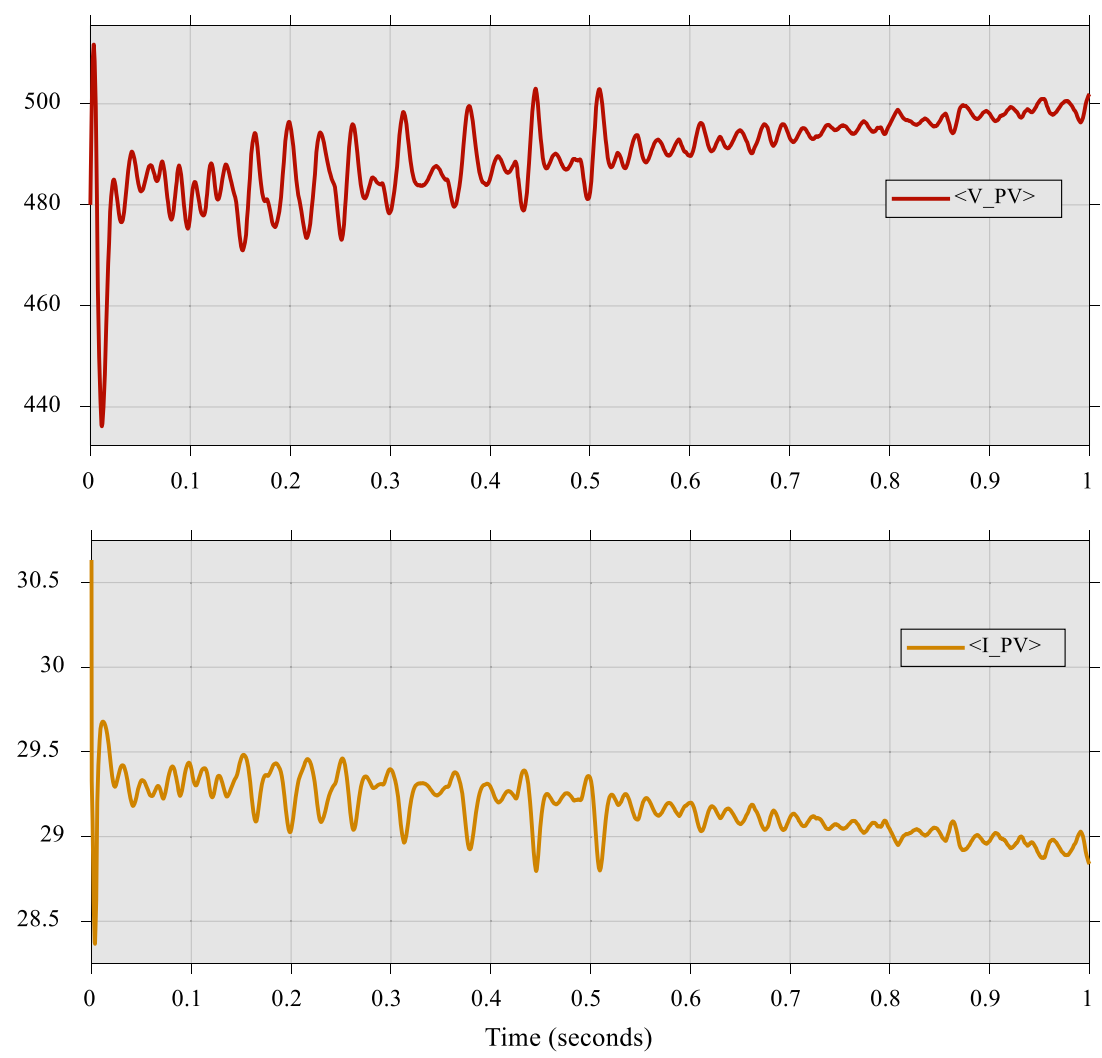
a)

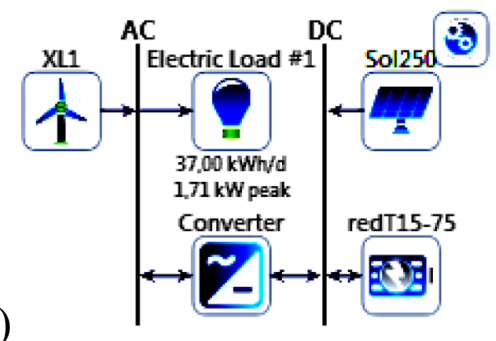

Daily Profile

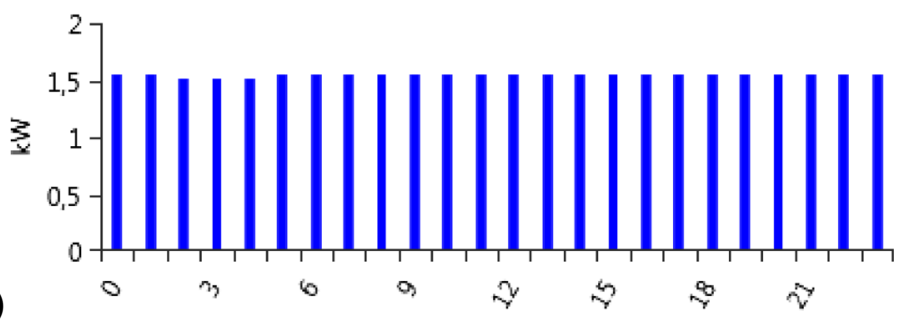

Fig. 7 a) General configuration, and b) Daily BTS (load) profile of the PV/wind HGES

characteristics at/under various temperatures and irradiances, Hermann-Wiesner method for I-V translation should be used [52]. An enhanced current pulsation smoothing parallel active filter (CPS-PAF) operation has been studied [53], in case of AC-PV module consisted of a single stage current source flyback inverter and PV module with electrical characteristics under $10^{3} \mathrm{~W} / \mathrm{m}^{2}, 25^{\circ} \mathrm{C}$ and $\mathrm{AM}$ of $1.5: \mathrm{P}_{\mathrm{DC}}=113,6 \mathrm{~W}, \mathrm{~V}_{\mathrm{DC}}=$ $33.235 \mathrm{~V}, \mathrm{I}_{\mathrm{DC}}$ (value of $\mathrm{PV}$ generator current at MPP) of $3.418 \mathrm{~A}, \mathrm{I}_{\mathrm{SC}}=8.28 \mathrm{~A}, \mathrm{~V}_{\mathrm{OC}}=37.8 \mathrm{~V}$ (Table 1). The inverter was selected based on high power factor regulation, very high power density, high efficiency, and simple structure [53-57]. Figure 6 shows simulation waveforms of the chosen PV module output current and voltage. The results show satisfactory elimination of the low frequency PV current and voltage ripple performed by the enhanced CPS-PAF configuration [53].

\section{Techno-Economic Evaluation}

Recognizing the extreme importance of rural areas, hub of agricultural production in areas of poverty, and within the Maghreb economies, this study tends to reduce power supply and communication costs, with an end goal of poverty reduction in the context of improved livelihoods [58].In terms of network coverage and tremendous impact on operation cost of running systems, Maghreb countries have not fill a positive role in the growth of TNs, due the current status of electric power infrastructure [31]. Standalone PV electrification systems can play a key role in a developing RAP of the Maghreb, where sun is shining and wind is blowing during almost the whole year [59]. To determine how different renewable, and hybrid systems interact with end-use demand, and based on availability and potential of RERs in RAP, HOMER (Hybrid Optimization Model for Electric Renewable [60]) software was used to model a hybrid energy system (HGES). Using Homer, Previous theoretical works on HGESs includes optimization and life-cycle cost [61-65], modeling, design methodology and size optimization of PV based standalone grid connected systems [66-69].

Moreover, Rozlan et al. [70] have optimized a stand-alone HGES, and other works [28, 71-74] have performed the techno economic feasibility analysis of different combinations of PV-wind hybrid systems. In terms of feasibility analysis, our system performed using HOMER.

was designed to power either a BTS and/or a SG, with load total capacity found to be $37 \mathrm{kWh} / \mathrm{d}$. To model the PV/wind HGES and decide its components size [49, 75], a peak load of $1.71 \mathrm{~kW}$ is considered. HGES is calculated basing on an hourly simulation under cycle charging strategy and in load following strategy, as well. The load is supplied by the solar PV and the wind turbine supplies the load when the batteries are discharged. The schematic diagram of the HGES utilized in the present study, and the daily average load profile are shown respectively in Figs. $7 a$ and $b$. HGES components are $3 \mathrm{~kW}$ solar PV system [48] with integration of $1 \mathrm{~kW}$ small wind turbine (Bergey BWC XL.1 [75]), providing a power production that depends on cut-in/cut-out speed, rotor diameter, hub height and wind speed (Fig.1) available for one from the three locations [76]. Scaled data of [77] to consider long-term annual averages, HOMER involves a clearness index from latitude and longitude of RAP.

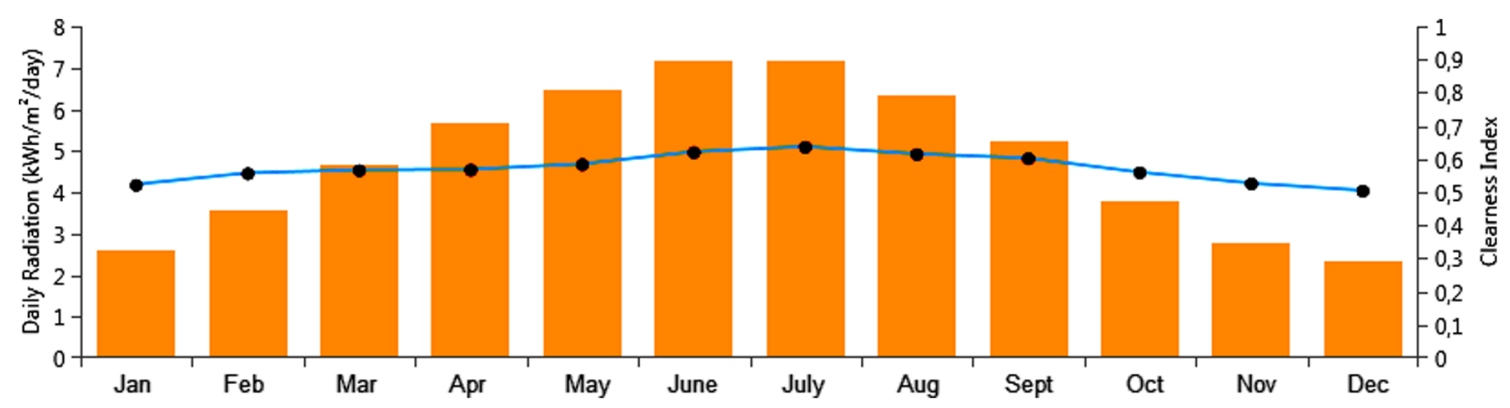

Fig. 8 Daily Solar Radiation with Clearness Index 


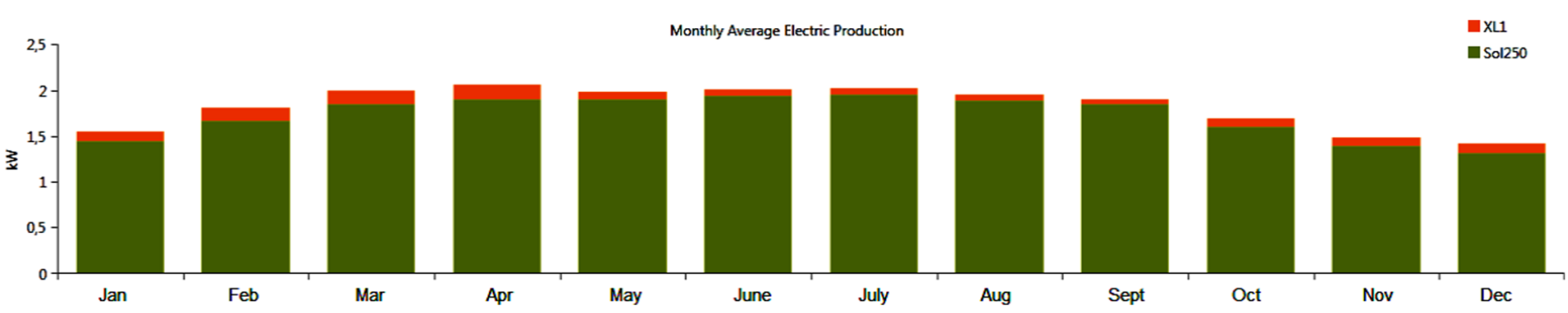

Fig. 9 RAP monthly average electric production

Figure 8 shows a monthly variation in solar radiation with the clearness index. These data serve as input to the HOMER for the analysis. The average daily solar radiation data with clearness index. Daily solar radiation ranges from 4.21 to $5.27 \mathrm{kWh} / \mathrm{m}^{2} /$ day and yearly average of $4.75 \mathrm{kWh} / \mathrm{m}^{2} /$ day. The most and least global solar irradiance is observed in July and January, respectively. Quarterly average wind speeds are respectively found to be $3.75 \mathrm{~m} / \mathrm{s}$, and ranged from 3.26 (in August) to $4.24 \mathrm{~m} / \mathrm{s}$ (in December (https://www.ncdc. noaa.gov/ and https://weatherspark.com/)) [77]). Average monthly profiles of wind speed for the three locations RAP including, is given in Fig. 1. The productions of HGES components are $15.143 \mathrm{kWh} /$ year (solar) and $0.849 \mathrm{kWh} /$ year, with contribution percentage of $94.7 \%$ and $5.31 \%$, respectively. AC primary load, in turn, consumes yearly $12.556 \mathrm{kWh} /$ year. Monthly average electric production of RAP is shown in Fig. 9 that illustrates the total annual electricity production from the grid, wind turbine, and solar PV systems in $\mathrm{kWh} / \mathrm{y}$. Renewable energy penetration effects on the consumption from the grid can be clearly seen. At RAP, the annual electricity production from GHES is mostly due to the high output power, specifically from the PV module. To reduce energy costs and improve BST or SMG operation, HOMER optimizes the NPC of a HGES, given by:

$\mathrm{NPC}=\mathrm{C}_{i}+\mathrm{C}_{r}+\sum_{t=1}^{N} \frac{\mathrm{C}_{o}+\mathrm{C}_{f}}{(1+i)^{t}}-\mathrm{C}_{s v}$

With $\mathrm{C}_{o}$ the operation and maintenance cost, $\mathrm{C}_{i}, \mathrm{C}_{r}$ the initial and replacement costs respectively, and $i$ and $N$ the discount rate and project life time respectively, and $\mathrm{C}_{s v}$ the salvage value, i.e. the present value of all revenues HGES earns over its lifetime, and the terms before are the present value of all costs HGES incurs over its lifetime, including fuel costs, emissions penalties, replacement costs, capital costs, operation and maintenance $(O \& M)$ costs, and costs of buying power from the grid $[20,78]$. Since it is of interest to discuss the electricity purchasing and selling for each month during the year, HOMER simulation requires financial parameters, and costs revenues include salvage value and grid sales revenue [79]. Results of NPC and LCOE are obtained as a solution by HOMER analysis, that are refined further by performing sensitivity analysis. The main economic output, total NPC (TNPC), is calculated by summing the total discounted cash flows in each year of the project lifetime [80]. TNPC is the value by which HOMER ranks system configurations for optimization results, and the basis from which it calculates the total annualized cost and LCOE $[62,81]$. In turn, the annualized cost $\mathrm{AC}=\mathrm{NPC}+\mathrm{CRF}$, function of capital recovery factor (CRF) and TNPC, are used to analyze HGES, so as LCOE and COE are given by Eqs. $6 a, b[76,82]$ as follows

$$
\begin{aligned}
L C O E & =\frac{\text { Capital } \times \mathrm{CRF}+\mathrm{O} \& \mathrm{M}}{\text { Energy generated }} \\
& =\frac{\text { Capital } \times \mathrm{CRF}+\mathrm{O} \& \mathrm{M}}{8760 \times \text { CapacityFactor }} \\
C O E & =T N P C \times C R F / \sum_{t=0}^{8760} \operatorname{Egen}(t)
\end{aligned}
$$

Besides simulating, HOMER also optimizes based on specific parameters given as inputs so that it provide a best combination scheme resulting in a much better performance in terms of techno-economic aspects. The operating cost (OC) is the annualized value of all costs and returns other than initial

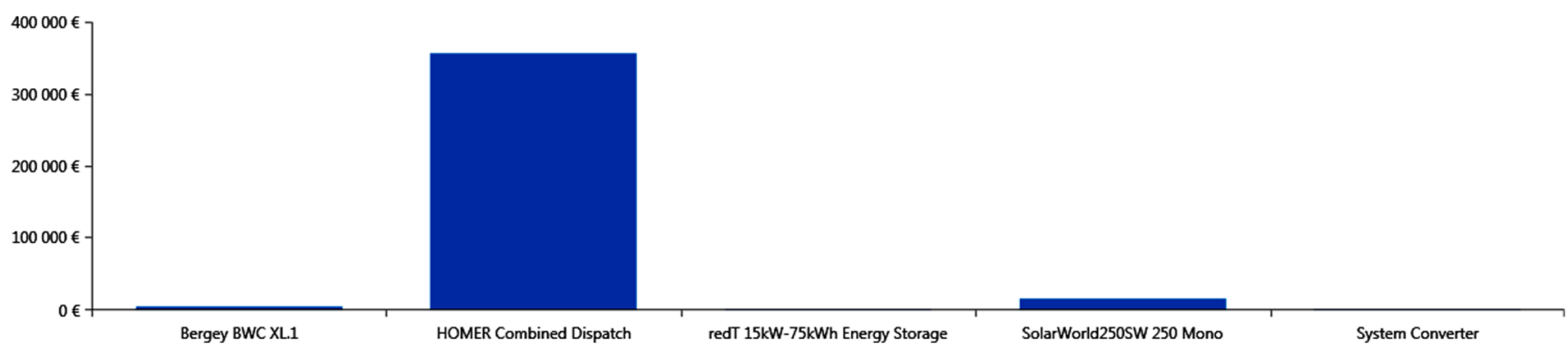

Fig. 10 Cost summary of wind/PV HGES at RAP 
Table 2 Cost parameters of components

\begin{tabular}{|c|c|c|c|c|c|c|}
\hline Component & Capital $(€)$ & Replacement $(€)$ & O\&M $(€)$ & Fuel $(€)$ & Salvage $(€)$ & Total $(€)$ \\
\hline Bergey BWC XL.1 & $4796,70 €$ & $5108,69 €$ & $112,32 €$ & $0,00 €$ & $-4230,30 €$ & $5787,41 €$ \\
\hline HOMER Combined Dispatch & $160,000,00 €$ & $0,00 €$ & $\begin{array}{l}196,025,43 \\
€\end{array}$ & $0,00 €$ & $0,00 €$ & $356,025,43 €$ \\
\hline redT $15 \mathrm{~kW}-75 \mathrm{kWh}$ Energy Storage & $89,39 €$ & $0,00 €$ & $2246,45 €$ & $0,00 €$ & $0,00 €$ & $2335,84 €$ \\
\hline SolarWorld250SW 250 Mono & $10,843,07 €$ & $0,00 €$ & $5348,53 €$ & $0,00 €$ & $0,00 €$ & $16,191,60 €$ \\
\hline System Converter & $433,39 €$ & $583,28 €$ & $235,99 €$ & $0,00 €$ & $-237,01 €$ & $1015,65 €$ \\
\hline System & $176,162,54 €$ & $5691,97 €$ & $203,968,73 €$ & $0,00 €$ & $-4467,31 €$ & $381,355,93 €$ \\
\hline
\end{tabular}

capital costs. HGES options, cost of energy generation, comparing between wind/PV contribution, and impact of energy generation from renewable energy systems on the livelihood of RAP have been reported here. The TNPC, LCOE and OC are $381.355,90 €, 0.9296 €$, and 6.280,62€, respectively. An initial capital for HGES is estimated to be $176.163 €$. Figure 10 shows a cost summary, where wind/PV HGES could be estimated as a most economical configuration. The cost of energy of HOMER is $0.214 € / \mathrm{kWh}$.

HGES in RAP is optimized here by considering different sensitivity parameters; Sensitivity analysis helps provide information on optimize systems for particular sensitivity variables. By varying the solar irradiation and wind speed, a sensitivity analysis was performed via simulating long-term implementation and searching components' sensitivities. Based on wind speed, solar irradiation, and grid electricity price $(€ / \mathrm{kWh})$ sensitivities, emissions, renewable fraction, NPC, and COE are simulated. Sensitivities were set respectively over $3.5-8 \mathrm{~kW} / \mathrm{m}^{2} /$ day, $6.9-8.8 \mathrm{~m} / \mathrm{s}$ and $0.084-0.336 €$ ranges, to analyze the feasibility of our HGES analyzed based on emission reduction and cost saving. HGES in RAP is feasible where grid electricity prices reveal to be more expensive, however global solar irradiation seem to sufficient. The results show that PV panels contribute highly than wind turbines, i.e. the solar energy impacts the configured HGES. As Fig. 10 shows, the cash flow summary of all components aims to a same load. It is worth noting here that cost parameters of various systems/components are based on data collected from
Fig. 11 Yearly PV and wind power outputs for RAP
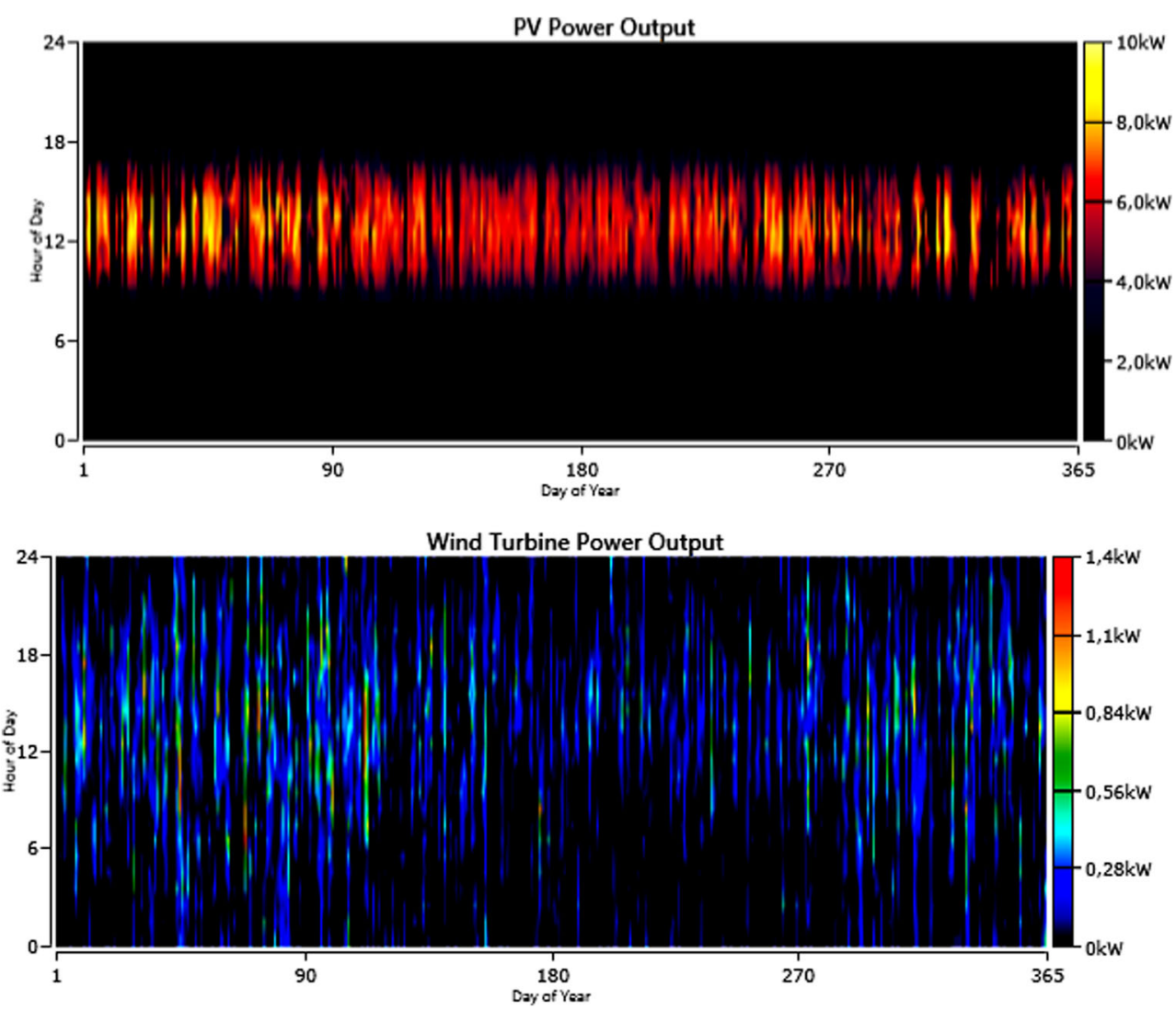
previous published literature and assumptions. When involving PV-wind HGES, installation cost is convenient with the optimized configuration for RAP. Components' cost details are listed in Table 2, where $9.92 \mathrm{~kW}$ of PV arrays, one wind turbine of $1 \mathrm{~kW}$, and power converter of $2.1 \mathrm{~kW}$. The yearly productions are $15.143 \mathrm{kWh} / \mathrm{yr}(\mathrm{PV} \sim 94.7 \%), 0.849 \mathrm{kWh} / \mathrm{yr}$ (Wind $~ 5.31 \%$ ), versus a yearly consumption of AC and DC primary load of 12.556 and $0 \mathrm{kWh} / \mathrm{yr}$, respectively. The total rated capacities, mean outputs, capacity factors of the PV module and wind turbine respectively of $(9.92 ; 1) \mathrm{kW}$, $(1.73 ; 0.0969) \mathrm{kW}$, and $(17.4 ; 9.69) \%$.

Figure 11 shows daily PV and Wind power outputs over a year. Power outputs increase with a reduction of total NPC and decrease of system's LCOE as well, showing that with a change in sensitivity variables component capacities increase, and therefore a change in the system configuration. Hence, a PV-Wind HGES proves to be the cheapest option compared to other systems. Energy costs for a grid-connected HGES are found to be less expensive compared to DG-based supply for similar load profiles, and the wind-turbine (though of less initial capital) has less contribution that that of the PVsource to supply a BTS in RAP. The results of optimization have that HGES is feasible and can provide reliable energy supply to RAP.

\section{Conclusion}

A first task of this paper was to model and simulate a PV module to be applied for a BTS or a SG at a remote areaprototype in the Maghreb, according to PV cells fundamentals, with model implemented on a MATLAB/Simulink environment. MPP was tracked effectively using single diode model of less simulation time due to simplified simulation structure and easy implementation. All parameters are evaluated in a good agreement with manufacturers' data sheet, which impact positively the HGES's performance. The study aimed also goal to study an integration of solar PV and small wind turbine assess the economic and financial feasibility all cases in terms of cost of energy. It has been proved that the proposed HGES is financially feasible with significant reduction in emission of greenhouse gases from grid energy supply. HOMER was suitable for carrying out techno-economic, feasibility, optimization and sensitivity analyses of stand-alone HGESs. The second task of this paper presents an overview of the current status of Maghreb's power generation in remote areas and a possible increase in the demand for electricity for the near future. Finally, It is worth nothing that any lack of technological infrastructure basis will have significant impacts on standard of living in rural and remote areas at the regional levels.

\section{References}

1. Ghiasi M, Esmaeilnamazi S, Ghiasi R, Fathi M (2020) Role of renewable energy sources in evaluating technical and economic efficiency of power quality. Technol Econ Smart Grids Sustain Energy 5:1. https://doi.org/10.1007/s40866-019-0073-1

2. Kumar S (2016) Assessment of renewables for energy security and carbon mitigation in Southeast Asia: the case of Indonesia and Thailand. Appl Energy 163:63-70

3. Hovenga EJS, Hovel J, Klotz J, Robins P (1998) Case report infrastructure for reaching disadvantaged consumers: telecommunications in rural and remote nursing in Australia. J Am Med Inform Assn 5(3)

4. Kumar YVP, Ravikumar B (2015) Integrating renewable energy sources to an urban building in India: challenges, opportunities, and techno-economic feasibility simulation. Technol Econ Smart Grids Sustain Energy 1(1):1-16. https://doi.org/10.1007/s40866015-0001-y

5. Iglesias JG, Bollen M (2011) Economic framework for power quality, JWG CIGRE-CIRED C4.107. Electra (91):91-95

6. Son PH, Son LH, Jha S, Kumar R, Chatterjee JM (2019) Governing mobile virtual network operators in developing countries. Util Policy 56:169-180

7. Noor S, Yang W, Guo M, van Dam KH, Wang X (2018) Energy demand side management within micro-grid networks enhanced by blockchain. Appl Energy 228:1385-1398

8. Cranston GR, Hammond GP (2010) North and south: regional footprints on the transition pathway towards a low carbon, global economy. Appl Energy 87:2945-2951

9. Abrahamsson L, Schütte T, Östlund S (2012) Use of converters for feeding of AC railways for all frequencies. Energy Sustain Dev 16(3):368-378

10. Goel S, Ali SM (2013) Hybrid energy systems for off-grid remote telecom tower in Odisha. India Int J Ambient Energy 36(3):116122

11. Li H, Li K, Zafetti N, Gu J (2019) Improvement of energy supply configuration for telecommunication System in remote areas based on improved chaotic world cup optimization algorithm. Energy 116614

12. Gungor VC, Sahin D, Kocak T, Ergut S, Buccella C, Cecati C, Hancke GP (2013) A Survey on Smart Grid Potential Applications and Communication Requirements. IEEE Trans Ind Inf $9(1): 28-42$

13. Usman A, Shami SH (2013) Evolution of communication Technologies for Smart Grid applications. Renew Sust Energ Rev 19:191-199

14. Siano P (2014) Demand response and smart grids-a survey. Renew Sust Energ Rev 30:461-478

15. Dragičević T, Siano P, Prabaharan SR (2019) Future generation 5G wireless networks for smart grid: a comprehensive review. Energies 12(11):2140

16. Khan AA, Rehmani MH, Reisslein M (2016) Cognitive Radio for Smart Grids: Survey of Architectures, Spectrum Sensing Mechanisms, and Networking Protocols. IEEE Commun Surveys Tutor 18(1):860-898

17. May P, Ehrlich HC, Steinke T (2006) ZIB Structure prediction pipeline: composing a complex biological workflow through web services. In: W.E. Nagel, W.V. Walter, W. Lehner, (eds.) Euro-Par 2006. LNCS, Springer, Heidelberg 4128 1148-1158

18. Zhou K, Yang S (2015) Demand side management in China: the context of China's power industry reform. Renew Sust Energ Rev 47:954-965

19. Kusakana K, Vermaak HJ (2013) Hybrid renewable power systems for mobile telephony base stations in developing countries. Renew Energy 51:419-425 
20. Margaret Amutha W, Rajini V (2015) Techno-economic evaluation of various hybrid power systems for rural telecom. Renew Sust Energ Rev 43:553-561

21. Wang Y, Huang Y, Wang Y, Li F, Zhang Y, Tian C (2018) Operation optimization in a smart Micro-grid in the presence of distributed generation and demand response. Sustainability 10:847

22. Wang R, Gu W, Wu Z (2011) Economic and optimal operation of a combined heat and power micro-grid with renewable energy resources. Autom Electr Power Syst 35:22-27

23. Sanjida M, Khandoker N, Haider M, Mustansir S (2012) Feasibility study of solar PV arrays in grid connected cellular BTS sites, International conference on advances in power conversion and energy technologies (APCET), (Book chapter) book e-ISBN : 978-14673-2043-6 , 978-1-4673-2041-2

24. Razmjoo AA, Davarpanah A, Zargarian A (2019) The Role of Renewable Energy to Achieve Energy Sustainability in Iran. An Economic and Technical Analysis of the Hybrid Power System. Technol Econ Smart Grids Sustain Energy 4:7. https://doi.org/10. 1007/s40866-019-0063-3

25. Kaluthanthrige A, Rajapakse AD, Lamothe C, Mosallat F (2019) Optimal sizing and performance evaluation of a hybrid renewable energy System for an off-grid power System in northern Canada. Technol Econ Smart Grids Sustain Energy 4:4. https://doi.org/10. 1007/s40866-019-0061-5

26. Arefin SS, Das N (2017) Optimized hybrid wind-diesel energy System with feasibility analysis. Technol Econ Smart Grids Sustain Energy 2:9. https://doi.org/10.1007/s40866-017-0025-6

27. Tazay A (2021) Techno-economic feasibility analysis of a hybrid renewable energy supply options for university buildings in Saudi Arabia. Open Engineering 11(1):39-55. https://doi.org/10.1515/ eng-2021-0005

28. Li C, Zhou D, Wang H, Lu Y, Li D (2019) Techno-economic performance study of stand-alone wind/diesel/battery hybrid system with different battery technologies in the cold region of China. Energy 116702. https://doi.org/10.1016/j.energy.2019.116702

29. Montazeri MM, Najjartabar-Bisheh M (2017) Optimizing technology selection for power smart grid systems: a case study of Iran power distribution industry (IPDI). Technol Econ Smart Grids Sustain Energy 2:6. https://doi.org/10.1007/s40866-017-0021-x

30. Welsch M, Howells M, Bazilian M, DeCarolis JF, Hermann S, Rogner HH (2012) Modelling elements of smart grids - enhancing the OSeMOSYS (open source energy modelling System) code. Energy 46(1):337-350. https://doi.org/10.1016/j.energy.2012.08. 017

31. Olatomiwa L, Mekhilef S, Huda ASN, Sanusi K (2015) Technoeconomic analysis of hybrid PV-diesel-battery and PV-wind-diesel-battery power systems for mobile BTS: the way forward for rural development. Energy Sci Eng 3(4):271-285

32. Hashimoto S, Yachi T, Tani T (2004) A new standalone hybrid power system with wind generator and photovoltaic modules for a radio base station, In Telecommunications Energy Conference, INTELEC

33. Koutitas G, Demestichas P (2010) A review of energy efficiency in telecommunication networks. Telfor J 2:2-7

34. Roy SN (2008) Energy logic: a road map to reducing energy consumption in telecommunications networks. in Telecommunications Energy Conference, INTELEC 2008. IEEE 30th international. IEEE

35. Rehman S, Al-Hadhrami LM (2010) Study of a solar PV-dieselbattery hybrid power system for a remotely located population near Rafha. Saudi Arabia Energy 35:4986-4995

36. Adaramola M, Oyewola O, Paul S (2012) Technical and economic assessment of hybrid energy systems in south-West Nigeria. Energy Explor Exploit 30:533-552
37. Nema P, Nema RK, Rangnekar S (2009) A current and future state of art development of hybrid energy system using wind and PVsolar: a review. Renew Sustain Energy Rev 13:209-2103

38. Neves D, Silva CA, Connors S (2014) Design and implementation of hybrid renewable energy systems on micro-communities: a review on case studies. Renew. Sustain Energy Rev. 31:935-946

39. Nandi SK, Ghosh HR (2010) Prospect of wind- PV-battery hybrid power system as an alternative to grid extension in Bangladesh. Energy 35:3040-3047

40. Ahmed M, Abdelrahem M, Kennel R (2020) Highly efficient and robust grid connected photovoltaic System based model predictive control with Kalman filtering capability. Sustainability 12:4542

41. Lekhchine S, Bahi T, Abadlia I, Bouzeria H (2017) PV-battery energy storage system operating of asynchronous motor driven by using fuzzy sliding mode control. Int J Hydrog Energy 42:87568764

42. Elgendy MA, Zahawi B, Atkinson DJ (2010) Comparison of directly connected and constant voltage controlled photovoltaic pumping systems. IEEE Trans Sustain Energy 1:184-192

43. Vordos N, Bandekas D, Nolan J, Fantidis J, Ioannou A (2013) Design and simulation of hybrid power system with wind turbines, photovoltaics and fuel cells. In Recent Advances in Energy, Environment and Development; WSEAS Press: Rhodes Island, Greece; pp. 19-24

44. Shayestegan M (2018) Overview of grid-connected two-stage transformer-less inverter design. J Mod Power Syst Clean Energy 6:642655

45. Ćalasan M, Abdel Aleem SHE, Zobaa AF (2021) A new approach for parameters estimation of double and triple diode models of photovoltaic cells based on iterative Lambert W function. Sol Energy 218:392-412

46. Messalti S, Harrag A, Loukriz A (2017) A new variable step size neural networks MPPT controller: Review, simulation and hardware implementation. Renew Sustain Energy Rev 68, 221-233

47. Batzelis EI, Kampitsis GE, Papathanassiou SA, Manias SN (2015) Direct MPP calculation in terms of the single-diode PV model parameters. IEEE Trans. Energy Convers. 30(1):226-236

48. Suthar M, Singh GK, Saini RP (2013) Comparison of mathematical models of photo-voltaic (PV) module and effect of various parameters on its performance. 2013 International Conference on Energy Efficient Technologies for Sustainability. Nagercoil:1354-1359

49. Chang C-H, Zhu J-J, Tsai H-L (August 2010) Model-based performance diagnosis for PV systems. SICE Annual Conference 2010: 2139-2145

50. Sunmodule solar datasheet type: SW 250 mono/Version 2.0 and 2.5 Frame model ref: SW-02-5001US 07-2012

51. Ding K, Bian XG, Liu HH, Peng T (2012) A MATLAB-SimulinkBased PV Module Model and Its Application Under Conditions of Nonuniform Irradiance, IEEE Transactions On Energy Conversion, VOL. 27, NO. 4, DECEMBER

52. Masters GM (2004) Renewable and efficient electric power systems. Wiley-IEEE Press, New York

53. Hishikawa Y, Doi T, Higa M, Yamagoe K, Ohshima H, Takenouchi T, Yoshita M (1996) Voltage-Dependent Temperature Coefficient of the I-V Curves of Crystalline Silicon Photovoltaic Modules, IEEE Journal of Photovoltaics, Vol. 8, No. 1, January 2018. W. Herrmann and W. Wiesner. Current-voltage translation procedure for PV generators in the German 1,000 roofsprogramme. In Proc. Internationales Sonnenforum, Freiburg, Germany, pp. 701-705

54. Kyritsis AC, Papanikolaou NP, Tatakis EC (2008) Enhanced current pulsation smoothing parallel active filter for single stage gridconnected AC-PV modules. 2008 13th International Power Electronics and Motion Control Conference, Poznan. 1287-1292. https://doi.org/10.1109/EPEPEMC.2008.4635446 
55. Kyritsis AC, Tatakis EC, Papanikolaou NP (2008) Optimum Design of the Current Source Flyback Inverter for decentralized grid-connected photovoltaic systems. IEEE Trans Energy Conv 23(1):281-293

56. Tan GH, Wang JZ, Ji YC (2007) Soft-switching flyback inverter with enhanced power decoupling for photovoltaic applications. IET Electr Power Appl 1(2):264-274

57. Kjaer SB, Blaabjerg F (2003) Design optimization of a single phase inverter for photovoltaic applications, in Proc. IEEE PESC'03, Accapulco (Mexico), 15-19 June, 3 1183-1190

58. Shimizu T, Wada K, Nakamura N (2006) Flyback-type single phase utility interactive inverter with power pulsation decoupling on the DC input for an AC photovoltaic module System. IEEE Trans Power Electron 21(5):1264-1272

59. Richardson D (2011) How can agricultural extension best harness ICTs to improve rural livelihoods in developing countries, http:// departments.agri.huji.ac.il/economics/gelb-how-11.pdf

60. Al-Karaghouli A, Kazmerski LL (2010) Optimization and lifecycle cost of health clinic PV system for a rural area in southern Iraq using HOMER software. Sol Energy 84(4):710-714

61. NREL (2009) HOMER. Available at http://www.homerenergy. com

62. Lambert T, Gilman P, Lilienthal P (2006) Micropower System Modeling with HOMER, Integration of Alternative Sources of Energy, by Felix A. Farret and M. Godoy Simoes, John Wiley \& sons, Inc, 379-418

63. Shiroudi A, Taklimi SRH, Mousavifar SA, Taghipour P (2013) Stand-alone PV-hydrogen energy system in Taleghan-Iran using HOMER software: optimization and techno-economic analysis. Environ Dev Sustain 15(5):1389-1402

64. Alsharif MH (2017) Optimization design and economic analysis of energy management strategy based on photovoltaic/energy storage for heterogeneous cellular networks using the HOMER model. Sol Energy 147:133-150

65. Marneni A, Kulkarni AD, Ananthapadmanabha T (2015) Loss reduction and voltage profile improvement in a rural distribution feeder using solar photovoltaic generation and rural distribution feeder optimization using HOMER. Procedia Technology 21: $507-513$

66. Gautam J, Ahmed MI, Kumar P (2018) Optimization and Comparative Analysis of Solar-Biomass Hybrid Power Generation System Using Homer. 2018 International Conference on Intelligent Circuits and Systems (ICICS)

67. Rawat R, Kaushik SC, Lamba R (2016) A review on modeling, design methodology and size optimization of photovoltaic based water pumping, standalone and grid connected system. Renew Sust Energ Rev 57:1506-1519

68. Lu Y, Wang S, Shan K (2015) Design optimization and optimal control of grid-connected and standalone nearly/net zero energy buildings. Appl Energy 155:463-477

69. Ma T, Yang H, Lu L, Peng J (2015) Pumped storage-based standalone photovoltaic power generation system: Modeling and techno-economic optimization. Appl Energy 137:649-659
70. Al-falahi Monaaf DA, Jayasinghe SDG, Enshaei H (2017) A review on recent size optimization methodologies for standalone solar and wind hybrid renewable energy system. Energy Convers Manag 143:252-274

71. Rozlan MBM et al (2011) The optimisation of stand-alone hybrid renewable energy systems using HOMER. Int Rev Electr Eng 6(4): $1802-1810$

72. Hossain M, Mekhilef S, Olatomiwa L (2017) Performance evaluation of a stand-alone PV-wind-diesel-battery hybrid system feasible for a large resort center in South China Sea, Malaysia. Sustain Cities Soc 28:358-366

73. Khan MJ, Yadav AK, Mathew L (2017) Techno economic feasibility analysis of different combinations of PV-wind-diesel-battery hybrid system for telecommunication applications in different cities of Punjab, India. Renew Sustain Energy Rev 76:577-607

74. Hossain M, Mekhilef S, Olatomiwa L (2017) Performance evaluation of a stand-alone PV-wind-diesel-battery hybrid system feasible for a large resort center in South China Sea, Malaysia. Sustain Cities Soc 28:358-366

75. Goel S, Sharma R (2017) Performance evaluation of stand alone, grid connected and hybrid renewable energy systems for rural application: a comparative review. Renew Sust Energ Rev 78:13781389

76. Small wind turbines for homes, farms and small businesses (2011) [Online]. Available: http://bergey.com/

77. Swarnkar NM, Gidwani L (2017) Economic and financial assessment of integrated solar and wind energy system in Rajasthan, India. 2017 International Conference on Computation of Power, Energy Information and Communication (ICCPEIC), Melmaruvathur, pp. 471-476. https://doi.org/10.1109/ICCPEIC. 2017.8290413

78. Maouedj R, Mammeri A, Draou MD, Benyoucef B (2015) Technoeconomic analysis of a standalone hybrid photovoltaicwind system. Application in electrification of a house in Adrar region. Energy Procedia 74:1192-1204

79. Surface meteorology and solar energy. [Online]. Available: https:// eosweb.larc.nasa.gov/sse/

80. Amutha WM, Rajini V (2016) Cost benefit and technical analysis of rural electrification alternatives in southern India using HOMER. Renew Sust Energ Rev 62:236-246

81. Yan J, Yang Y, Elia Campana P (2019) City-level analysis of subsidy-free solar photovoltaic electricity price, profits and grid parity in China. Nat Energy 4:709-717

82. Sen R, Bhattacharyya SC (2014) Off-grid electricity generation with renewable energy technologies in India: an application of HOMER. Renew Energy 62:388-398

Publisher's Note Springer Nature remains neutral with regard to jurisdictional claims in published maps and institutional affiliations. 